DOI 10.14746/ssp.2021.1.5

Lucyna RAJCA

Jan Kochanowski University in Kielce

ORCID ID: 0000-0002-3947-1729.

\title{
The position of mayor within local authority relations in Hungary and Poland in a comparative perspective
}

\begin{abstract}
The study aims to compare the position of Hungarian and Polish mayors in horizontal relations of power, considering the changes taking place in this area over the last few years. The article presents the institutional and legal conditions of local leadership in Hungary and Poland, as well as the role of councils with regard to the executive body. It also describes the systems of election to legislative bodies, which is one of the factors influencing the status of councils and relations within a local authority. The results of the analyses show that there are differences in the positions of Hungarian and Polish mayors and that the relations within local authorities in both countries have been affected by convergent and divergent trends. The study uses the comparative method and an institutional-legal approach, as well as the historical method.
\end{abstract}

Key words: position of mayor, Poland, Hungary

\section{Introduction}

The objective of many institutional reforms in the last two to three decades has been to strengthen the role of local executive power over legislative power, and to provide strong, visible, and effective leadership. The reasons for these reforms were the lack of transparency and accountability in local decision-making bodies (deficit of local democracy) and the diminishing ability of traditionally organized local government to deal with increasingly complex issues and challenges (management efficiency deficit) (Wollmann, 2008, pp. 279-280). One way to strengthen political leadership was to introduce direct mayoral elections. The reforms have resulted not only in a change in the methods of election and the scope of executive power, but also in the relationship between executive bodies and councils. At the same time, the strengthening of the political execu- 
tive in many systems of local government has raised concerns about the diminishing role of councils themselves, thus the need for them to restore their position has been addressed.

One of the most important factors influencing the relationship between the executive and the legislative bodies is the adopted model of the local executive. Poul E. Mouritzen and James Svara distinguished four basic types of executive power organization (Mouritzen, Svara, 2002, pp. 55-56): the strong mayor model (the elected mayor has a strong position as compared to the council, and is given control of the local administration); the committee-leader form; the collective form; and the councilmanager form. Although this typology is based on formal institutional arrangements, Mouritzen and Svara emphasize that informal rules and norms also play a role in shaping these four types of executive power. Based on the classification of leadership models formulated by Mouritzen and Svara, Hubert Heinelt and Nikos Hlepas in 2006 included Poland and Hungary among local government systems with a "strong executive mayor" (Heinelt, Hlepas, 2006, p. 36). However, the indicator of the power of the Polish and Hungarian mayors in local government structures, based on several variables, was not the highest among the seventeen European countries studied and placed them 6th and 8th respectively (out of a maximum of 12), thereby placing both countries more or less in the middle of the ranking. In 2015, Hubert Heinelt, Nikos Hlepas, Sabine Kuhlmann, and Paweł Swianiewicz recalculated this indicator based on seven different institutional variables (including the method of the mayor's election, the scope of competence with regard to the legislative body, including chairing the council, the ease of dismissal procedures before the end of a term of office, ensuring the majority of the mayor's party in a council by electoral law, the independent appointment of the head of the office and other leading officials). The research by these authors confirmed that Poland and Hungary belong to the group of countries with a strong position of mayors. In both countries, the mayor's power index was the same, at 10. Nevertheless, its value was not the highest on the European scale (Heinelt, Hlepas, Kuhlmann, Swianiewicz, 2018, pp. 19-78). In several other countries, the mayor's dominance over other participants in local political life is even greater (France (13), Spain, Slovakia, Greece and Iceland (12), Slovenia (11), Italy (10.5)) (Swianiewicz, Krukowska, 2018, p. 30; Swianiewicz 2018, p. 57).

The aim of this article is to identify the similarities and differences regarding the positions of Hungarian and Polish mayors in horizontal re- 
lations of power, considering the changes recently taking place in this area and finding an answer to the question of whether the positions of Polish and Hungarian mayors can actually be regarded as equally strong. The hypothesis assumes that there are differences in the positions (power) of Hungarian and Polish mayors, in favor of the former, and that both convergent and divergent trends have influenced the shape of relations within local authorities in both analyzed countries. The paper is divided into five parts. The first two cover the institutional and legal conditions of local leadership in Hungary and Poland, i.e. the method of appointing the executive body and the area of its competence, also regarding councils. Additionally, a description of the role of councils towards the executive body is provided. Further, the paper examines the method of election to legislative bodies, which is one of the factors influencing the status of councils. The conclusion addresses the proposed hypothesis and points out the convergences and divergences in the implementation of reforms. The article uses the comparative method and the institutional-legal approach. Research studies on local government in Poland and Hungary employing a comparative perspective have been scarce, especially in the last decade. ${ }^{1}$

Poland and Hungary are particularly interesting countries in which to conduct comparative research. Firstly, they share common historical experiences, traditions, culture, and values. Secondly, both Poland and Hungary were in a similar initial position concerning the implementation of the idea of local government. Thirdly, until recently, both countries were leaders in decentralization in Central and Eastern Europe. In both countries, the municipalities gained a much stronger position than higherlevel units by being given the responsibility for most public services, tax control, greater financial independence, and a general competence clause in line with the subsidiarity principle. Fourthly, in these countries, the reforms and changes undertaken in recent years have aroused intense international interest and sparked concerns about a breach of the fundamental principles of the rule of law and liberal democratic values. After the victory of the right-wing party Fidesz in 2010, the constitution was changed in Hungary and a thorough reform of the state began, which led to radical recentralization and weakening the role of local government. In Poland, after the conservative party Law and Justice took power in 2015, the poli-

${ }^{1}$ The article is a modified and extended English version of one of the chapters of the author's book entitled Reformy samorzadu terytorialnego na Wegrzech $i$ w Polsce, Dom Wydawniczy ELIPSA, Warszawa 2019. 
ticians of the ruling party have frequently referred to Hungarian politics. Centralizing tendencies intensified, which resulted in the introduction of changes in the local government system, including the position of the mayor in relations within local authorities.

Although the public administration has been recentralized in both countries, the scale of this phenomenon has been much smaller in Poland than in Hungary (see Rajca, 2020, pp. 133-151). In both countries - as can be seen from many reports and academic literature - there has been a 'backsliding' of democracy, but in Poland, this process has taken place to a much lesser extent than in Hungary (see: Meyer-Sahling, Toth, 2021; Freedom House, 2020, p. 3). A separate threat to local government, but also to the state, is the growing populism in Poland and Hungary (also visible in other countries), resulting from the crisis of trust in the institution of liberal democracy. Populism, focusing on consolidating the belief that the interests of citizens are ensured by the central state authorities, in fact, questions the entire structure of multi-level governance and contributes to the weakening of the position of local government (Izdebski, 2017, p. 25).

\section{The position of mayor in Hungary}

In Hungary, direct elections of mayors in all municipalities were introduced in 1994. Previously, the method of selecting a mayor was based on the size of the municipalities. In municipalities of up to 10,000 inhabitants, the mayor was elected directly, in larger ones by the council. The mayor could not be dismissed during their (4-year) term of office. The council could elect their deputy (or deputies). The mayor was the political and administrative leader of local authorities, the superior of local government employees and the head of the office. The head of administration in municipalities (traditionally referred to as "notary") was responsible for the tasks of sectoral state administration and the tasks of local government. The position involved ensuring the legality of the activities of the local administration by examining the compliance of the decisions of the council and the mayor with the law. As Agnieszka Pawłowska and Katarzyna Radzik claim, the relatively strong position of the professional head of administration created the conditions for shaping a less party-based local politics (Pawłowska, Radzik, 2008, pp. 36-38). For this reason, the above-mentioned authors included (2008) the Hungarian local government system in the technocratic model. 
From 1994, mayors could hold a parliamentary mandate. Initially, about 10 percent of mayors were at the same time Members of Parliament. Later, the percentage of mayor-parliamentarians increased gradually in each subsequent local election (Pálné Kovács, 2016, p. 804). This accumulation of seats is emblematic of southern European local government systems. A large number of Hungarian mayors received parliamentary seats (almost 20\%), but this fact did not translate into a significant increase in the prestige of local interests and lobbying forces. It is worth emphasizing that the drastic loss of competence of local government resulting from the passing of the Act on Local Government in Hungary in 2011 was supported by mayor-parliamentarians associated with the ruling party. With the local elections in 2014, combining the mandate of mayor with the mandate of an MP was banned (Dobos, 2016, p. 85). Another important change based on the new Basic Law (Article 35.1) introduced before the elections to local governments in 2014 was the extension of the term of office of councilors and mayors from four to five years.

In 2010, the abiding 1994 regulation concerning the local government electoral system was amended (Act No. L of 2010 on the election of local government representatives and mayors). The new rules for the functioning of representative bodies came into force on January 1, 2013. The amendment did not affect the direct election of mayors exercising political leadership. Mayors are elected by first-past-the-post (FPTP), in a single vote. An absolute majority is not required. One of the most important factors in the election and actions of a mayor is membership of a political party. Before 2013, the notary heading local administration was appointed by the local government council based on a competition (they had to meet the education requirement of having a degree in law or economy combined with practical experience in the administration sector). Since the beginning of 2013, the notary has been appointed by the mayor for an indefinite period, which enforces the notary's loyalty to the mayor. Moreover, the powers and tasks of notaries were reduced after the creation of district offices (January 1, 2013). Before that, the notary had a dual role: that of the head of the local administration (head of the mayor's office) and of the representative of the central administration. After the change, a notary could essentially only deal with local matters. Due to the important role of political parties and the much weaker position of a notary than before, it is currently difficult to classify the Hungarian local government system as a technocratic model. 
The Hungarian mayor is not only the executive body but also serves the role of a member and chairperson of the municipal council. As the chairperson, the mayor has an impact on the activities of the decisionmaking body, as they convene sessions, conduct debates, set the agenda, sign minutes of meetings, and represent the representative body. As an executive body, the mayor performs the resolutions of the representative body, assigns duties, performs the tasks and assumes responsibilities specified in legal regulations concerning administration, and performs the role of an employer, also in relation to heads of municipal institutions (Czyż, 2009, p. 276).

In smaller municipalities, a mayor may be employed on a part-time basis. At a mayor's request, a council may appoint their deputies, currently also from outside the council (previously only from among councilors, which enabled the ruling party to fill more positions in the patronage system). The government did not limit the number of terms of office - probably because the representatives of the ruling Fidesz party hold the functions of mayors in the vast majority of cities. Hungarian mayors had already been of great importance, but the reform introduced by the 2011 law on local government in Hungary strengthened their position even more. First of all, they have the right to veto resolutions which, in their opinion, are harmful to the municipality. In this case, the re-adoption of the resolution requires a qualified majority. Before the reform, the mayor could only initiate another debate on the matter in such a situation (Czyż, 2009 , p. 276). Moreover, other capabilities of the mayor have been extended, including financial ones. For example, a mayor can decide an urgent matter between two council sessions. Under the 2011 Local Government Act, a mayor loses their mandate for reasons such as a loss of electoral rights, declaration of a conflict of interest, damage to dignity necessary to hold office, court sentence, repeated violations of the law and negligence, resignation, dismissal under supervision, self-dissolution of the council local government and dissolution of the council by parliament (Balázs, et al., 2014, pp. 28-29). It is not possible to dismiss a mayor in a referendum before the end of their term of office.

\section{The position of mayor in Poland}

In Poland, since the restoration of municipal government, village heads, mayors, and presidents of cities have been elected by municipal 
council and chair the collective executive body (board). The mayor and their deputies do not have to be members of the council. The capabilities of the council gave it a dominant position in the structure of local government. At the request of the chairman of the board, the council appointed the chairman's deputies. Since 1995, the mayor has been eligible to propose candidates for other members of the management board. Despite the gradual strengthening of the position of the executive body and its chairman, the position of the council has remained stronger due to its power to appoint and dismiss the chairman of the board and the board as a whole. Management boards, selected through political negotiation, have consisted of representatives of political groups that were often alien to each other. The elected mayor largely focused on building good relations with them. There was a temptation to club together with the councilors. This blurred responsibility, and the municipality office was treated as a political sinecure, not an apparatus for fulfilling obligations towards voters. The weak position of municipal executive authorities, and in particular the unstable position of the mayor, was seen by many experts as a drawback of the Polish local government system. Local government was losing public trust. It seemed that the previous formula of the executive body had stopped working (Rajca, 2002, pp. 3-13). Therefore, in 2002 - with support from the vast majority of citizens - direct elections of municipal heads, mayors, and city presidents were introduced. The division of tasks and powers between the council and the executive body remained unchanged. At the same time, the number of councilors decreased significantly. The mayor is elected by absolute majority. A second round of elections takes place in the absence of such a majority.

The introduction of direct elections for mayor aimed at creating a new system of relations between the council and the executive body, also selected through general elections. This system, based on cooperative rather than adversarial relations, was to prevent antagonistic relations between these organs. The necessary condition for the formation of this type of relationship in the municipality is the existence of an appropriate political base in the council, capable of supporting the policy implemented by the mayor. This goal has been achieved by joining the mayoral election and the election of councilors, so that the mayor's supporters can become a part of the council. However, the electoral law has not ensured a majority of the mayor's party in a council. Making the effectiveness of the mayor's work dependent on the results of the election to the legislative body weakens the mayor's political position in the local government 
structure. In practice, it was not possible to permanently eliminate the conflict between the executive and the controlling body. In municipalities where the mayor represents a political party different from the majority of the council, conflict has become the rule of the coexistence of both bodies (Kowalik, 2015, p. 163). The lack of a majority in a council forces a mayor to negotiate with various factions or individual councilors to obtain support for specific projects (Kuć-Czajkowska, Wasil, Sidor, 2017, p. 37). Most frequently, however, a mayor has majority support obtained as a result of elections, or as a result of forming a post-election coalition.

Since 2002, the position of mayor has strengthened substantially. First of all, the selection and dismissal of a mayor no longer depends on the municipality council. A council may take actions aimed at dismissing a mayor in a referendum, but the legal regulations make it difficult to dismiss a mayor on the initiative of a council. The mayor's capacity to appoint their deputy (deputies) and impose organizational regulations (through an ordinance) as well as single-person representation of the municipality outside strengthens their position from the point of view of the decision-making body. The change introduced in 2002 ultimately put the executive body in the dominant position in the system of municipal government. It also diminished the role of municipal councils and weakened their controlling functions. Moreover, in the last decade, local leadership has been strengthened as a result of multiple election successes by the same leaders. Mayors themselves have been aware of the increase in their political position: as many as 83 percent of them believe that their position in relation to the municipal council has strengthened in recent years (Swianiewicz, Krukowska, 2018, p. 44).

The Polish mayor is a single-person executive body. Unlike the Hungarian mayor, the Polish mayor cannot simultaneously occupy the position of chairman of the council or hold the mandate of a councilor. Moreover, the Polish mayor is always employed full-time and employs their deputies ( 1 to 4 ) through a one-person ordinance. Polish mayors may not veto the resolutions of the regulatory and supervisory body - there is no procedure for challenging a decision of a council that is lawful, but irrational and harmful to the local community. Such procedures exist in Hungary and some other European countries. There is no clear line between the political function obtained through elections and the clerical function gained by appointment, or as a result of a competition. The originally planned position of the city head was replaced by the position of a secretary, whose role is not well defined. The Polish mayor is the superior 
of local government employees and heads of municipal organizational units. In practice, this means that the municipal council is deprived of the organizational and technical capabilities for independent functioning. The regulations (Electoral Code) provide several reasons for the termination of a mayor's mandate by law, including (unlike in the case of Hungarian mayors) also through a local referendum conducted both on the initiative of a council and residents. ${ }^{2}$ The regulations do not provide for such reasons as the damage to credibility necessary to hold office or the dissolution of the council, as they do in the case of Hungarian mayors. The dissolution of a council by the Sejm of the Republic of Poland at the request of the Prime Minister or the dismissal of a council as a result of a local referendum does not result in the dismissal of a mayor. In 2001, combining the mandate of a mayor and an MP was banned.

Mutual relations between the mayor and the council are based on tasks and competencies. The tasks of the Polish mayor include: ensuring compliance with the resolutions of the municipality council and performing the tasks set out by law; preparing draft resolutions of the council, including a budget draft; preparing development programs; specifying the manner of implementing resolutions; managing communal property; budget execution; and hiring and dismissing heads of organizational units (Article 30 of the Act on Municipal Government). The tasks of the council include specifying the mayor's salary, controlling the directions of their activities, adopting a resolution on discharge in respect of the implementation of the budget and a resolution on a vote of confidence, exercising control over the mayor's activities, and deciding on holding a referendum on their dismissal.

The literature on the subject shows that although institutional and legal solutions significantly affect the cooperation of local government bodies and their mutual relations, these relations also depend on nonlegal factors, such as the balance of power generated as a result of local elections, political culture, local customs, the interpersonal skills or personality traits of people performing functions in local government authorities. Despite the same legal framework, there are different styles of cooperation between municipal councils and mayors (Kotarba, 2016,

${ }^{2}$ Appeal referenda take place quite frequently but rarely are important. In the 2014-2018 term of office, there were 46 referenda on dismissing local government bodies. The vast majority (31) concerned dismissal of the mayor. Only six referenda were valid, the remaining ones did not meet the required turnout threshold (no less than $3 / 5$ of the number of people participating in the election of the dismissed body). 
pp. 218, 226). Taking these conditions into account, Bogusław Kotarba distinguishes three models of mutual relations in Polish municipal government: idyllic (this may develop, for example, in a situation where both bodies represent the same political option); optimal (where a majority supporting the mayor is formed in the municipal council - regardless of the political option/election committee) and conflict (where the mayor has no majority support in the council).

In Poland, the multi-reelection of mayors has become a common phenomenon (especially in small municipalities, due to weak electoral competition, but also present in a large group of big cities), which contributes to strengthening their position in relation to the decision-making body. There has been a postulate to limit the possibility of being re-elected. During the thirty-year history of modern municipalities, a relatively stable group of local leaders has been formed. The research shows that the percentage of Polish mayors who have held office for over 12 years is among the highest in Europe (except for France) (Krukowska, 2017, p. 16). The literature and reports prepared by academics emphasize that the unlimited term of office of executive bodies empowers favoritism and gives rise to an unfair division of power, nepotism, corruption, and limits civic participation. The other side of the discourse was against limiting the number of terms of office of mayors. It pointed out that the forced departure from the position of a reliable person who acts for the benefit of the local community may adversely affect the matters of the local community (Chmielnicki, 2011, p. 9) and that limiting the number of terms of office is an expression not only of a paternalistic approach on the part of the legislator, but also an expression of a lack of trust in the competences and qualifications of members of the local government community. Moreover, it constitutes a restriction of local government since it deprives the inhabitants of the possibility of free choice (Bujny, Ziemski, 2015, p. 30).

The legislator presumably shared the opinions of the supporters of limiting the term of office, since in 2018 the dual term of mayors was introduced (the change will de facto enter into force from 2028). Researchers point out that the effectiveness of limiting the term of office of mayors may be small, however, if there is the phenomenon of fictitious "exchange", common in other European countries (Italy, Portugal) when a person appointed by the current mayor and exercising power according to the already existing rules fills the position (Swianiewicz, Krukowska, 2018, p. 39). The problem of multi-reelection in Polish local governments is a complex issue that is difficult to unequivocally assess, requiring an 
analysis that takes into account legal, political, sociological, economic, and managerial aspects.

After the introduction of direct elections of mayors in 2002, some leaders have gradually become independent of political parties, forming their own local factions. The multiplicity of local committees and groups has become a characteristic of Polish local government. As a result, municipal executive bodies are not so much politics-based any longer. Research carried out in 2015 by Paweł Swianiewicz and Adam Gendźwiłł shows that Polish mayors are lowly politicized. The percentage of Polish mayors who are members of political parties was the lowest in Europe and amounted to approximately 35 percent, ${ }^{3}$ while in the case of Hungarian mayors this percentage was around 80. In Hungary, the percentage of mayors belonging to a political party has increased significantly in recent years, which may be related to the sharp rise in popularity of the Fidesz party, as the most important local government posts have been filled by its members. Although many Polish mayors have declared that they do not belong to any political party, most of them described their views as right-wing. Only Hungarian mayors have been more definitive in their right-wing declarations. Nowadays, the right-wing slightly prevails over the left-wing orientation across the continent (Swianiewicz, Gendźwiłł, 2017, pp. 22-25). Polish leaders have declared that the intensity of the political conflict in their municipalities is lower than that declared by Hungarian mayors (Kopcińska, 2017, pp. 26-27).

In Poland, a phenomenon of autocratic dysfunction is said to have emerged. Its result is shifting real power from the legislative bodies towards executive bodies, which is unfavorable from the point of view of local democracy (Bober, Hausner, Izdebski, et al., 2013, p. 29). ${ }^{4}$ In order to counteract this dysfunction, since 2018, the position of the decision-making and control body in relation to the executive body has been strengthened, following the introduction of the duty to prepare and submit to the council a report on the state of a local government unit. Citizens have the right to participate in the debate on the report. The debate over the report concludes with a vote on granting the executive body a vote

${ }^{3}$ Many mayors are in fact affiliated with parties, although they run for elections from the list of local committees.

${ }^{4}$ Research has shown a relationship between the size of local government and the relationship between the mayor and the council. In the largest cities, these relations are more balanced than in smaller local governments (Lackowska, Swianiewicz, 2018, p. 20). 
of confidence. If the mayor is not granted a vote of confidence in two subsequent years, a municipal council may adopt a resolution to hold a referendum on the mayor's dismissal (Act of 11 January 2018). Giving more controlling capabilities to the decision-making and control body has also resulted in introducing regulations related to dealing with complaints about the activities of the executive body and local government organizational units. The solutions introduced are aimed at improving the mechanisms of competence relations between municipal authorities to implement the postulate of checks and balances.

\section{The electoral system for decision-making bodies in Hungary and Poland}

One of the factors influencing the status of legislative bodies is how they are elected. In the elections to municipal councils in Hungary and Poland, there is both a proportional representation and a majority system. In Hungary, municipalities with fewer than 10,000 inhabitants have a majority system; voters can vote for many candidates. Municipalities with more than 10,000 inhabitants and capital city constituencies use a mixed electoral system; some councilors are elected in single-mandate constituencies, and some from party lists in a proportional system. With the victory of the Fidesz party in the parliamentary elections in 2010, the local government electoral law underwent modifications; first in 2010 and then in 2014. The number of councilors elected according to the majority system dropped by about 25 percent, whereas the number of councilors elected on party lists decreased by about 50 percent. Moreover, the election thresholds increased from 4 to 5 percent. As a result, the requirements for standing as a candidate at elections according to the proportional system has become more difficult to meet for small organizations (usually civic) and independent candidates. The main national parties (now Fidesz) have benefited from the change, as they can dominate in single-mandate constituencies and can meet the conditions for drawing up party lists. At the same time, legal regulations have created opportunities for the ruling party to fill positions with their supporters in local offices (Dobos, 2016, pp. 80-88). ${ }^{5}$ Since 2014, councilors, as well as

${ }^{5}$ In the last local government elections held in October 2019, the Fidesz-KNDP coalition maintained its position as by far the strongest political grouping in Hungary. The ruling coalition, on the other hand, failed in Budapest and some large cities. It is there that Fidesz has the most opponents. It enjoys the greatest support in the prov- 
mayors, have been elected for a five-year term (previously it was a four-year term). The electoral law for the local government of Budapest has changed: the Assembly of Budapest consists of the 23 mayors of the capital's districts and nine representatives elected in a proportional system. The mayors of the districts and the mayor of the capital (Lord Mayor) are directly elected (Kancelaria Senatu, Biuro Analiz i Dokumentacji, 2015, p. 104).

In Poland, in 1990, municipalities with up to 40,000 inhabitants elected their councilors in single-mandate constituencies, whereas larger municipalities elected their councilors in multi-mandate constituencies, using a proportional system. In the following years, local government election law has been amended many times. Before the local government elections in 2014, municipalities of up to 20,000 inhabitants used the majority system, while larger municipalities, cities with county status, counties, and provinces used a proportional system. In Poland, there was quite a common belief that the adoption of the proportional system led to making local elections more party-based, thus weakening the civic factor (Czakowska, Czakowski, 2011, p. 219). In 2014, the PO-PSL (Civic Platform - Polish People's Party) parliamentary coalition introduced a majority system in single-mandate constituencies in all municipalities, except for cities with county status. Introducing single-mandate constituencies in all municipalities has diminished the representativeness of councils, and in many cases strengthened the mayor's election committees thus giving rise to a "local presidency" (Gendźwiłł, 2015, pp. 67-80). At the beginning of 2018, the electoral system used before 2014 was restored in Poland. So, unlike in Hungary, recently there has been an increase in the importance of proportional elections. ${ }^{6}$ This diverse electoral system, in small municipalities - the majority system, in large ones - the proportional system, has influenced the composition of councils and may affect the relationships between bodies.

\section{Conclusion}

There have been both similar and different trends in shaping the position of the mayor in relations within local authorities in the studied coun-

inces. In this respect, the situation of Viktor Orbán's party is similar to that of Law and Justice in Poland.

${ }^{6}$ In the last local government elections held in October 2018, with a fairly high turnout (54\%), Law and Justice received the most votes in the country, more than in 2014. The ruling party, on the other hand, failed in Warsaw and other large cities. 
tries. In both local governments, developing democratic local institutions started with councils as the dominant actors of the local scene. Over time, top-down reforms have led to establishing a strong monocratic executive body (a "presidential" model of local political leadership), mainly as a result of the introduction of universal and direct elections: in Hungary in 1994 and Poland in 2002. In both countries, the position of mayors has strengthened over the last decade. In Poland, the overly strong position of the mayor was considered unfavorable from the point of view of local democracy, and for this reason, the role of the council in relation to the executive body was strengthened in 2018. In both countries, the term of local government bodies was extended from four to five years (in Poland in 2018, in Hungary in 2014) and combining the mandate of local government and the mandate of an MP (in Poland in 2001, in Hungary in 2014) was banned. In both local governments, the political factor plays an important role in the relations between the council and the mayor, i.e. whether or not the mayor and the majority in the council identify with the same political party. Polish mayors, however, lean much less towards any political party than Hungarian mayors. In recent years, most Polish and Hungarian mayors have declared right-wing views. At the same time, it should be emphasized that in both studied local government systems the relations within the local government are variable and are often based on ad hoc arrangements concerning specific issues.

The main difference between Hungarian and Polish mayors is that the former serve the function as both the executive authority and chairman of the local council and councilor, while the latter can only act as the executive authority. The Polish mayor, unlike their Hungarian counterpart, has little influence, at least formally, on the work of the municipal council. They do not have the right to challenge the decision of a council which is lawful, but irrational and harmful to the local community. Dismissing a mayor by referendum is possible only in Poland. Limiting the number of terms of office of mayors and strengthening the council in relation to the executive body (from 2018) took place only in Poland. Moreover, the electoral system in Hungary is more conducive to the formation of a "local presidency" than in Poland. For all these reasons, the position of the Hungarian mayor is clearly stronger compared to the Polish executive body. The nature of changes in the electoral system to local councils is also different. In Hungary, the majority electoral system has strengthened in recent years (in order to facilitate the victory of the ruling party), while in Poland, a similar trend was present for a short time until recently 
(2018), when the proportional model, which limits the possibility of gaining a majority capable of governing independently, began to prevail. The changes in the Hungarian and Polish electoral systems confirm the thesis presented in the literature about the unfinished process of changing the electoral systems in the countries of this region.

To sum up, the hypothesis formulated at the beginning should be considered as positively verified. It is worth emphasizing that the relations within local authorities are influenced by both institutional and legal factors, including the adopted model of local leadership, as well as several other factors, such as political influence, opposition power, political culture, method of election to decision-making bodies, the national and international context in which local governments function or the style of leadership (RadzikMaruszak, 2019, pp. 157-158). It seems that both in Poland and Hungary institutional and legal factors have played the greatest role. The top-down introduction of a strong monocratic executive body has significantly limited the role of councils and made mayors leaders of municipalities. This fact confirms the thesis put forward in the literature that the strong position of a mayor leads to the weakening of the role of the legislative body on the local political scene. As the situation has caused concern, the position of councils in Poland is now being restored.

It is difficult to unequivocally assess the extent to which the strengthening of the mayor's position in the local government system is conducive to the implementation of the idea of participatory governance, and to what extent it is less favorable of the concept. A lot depends on the attitude of the executive body to democratic innovations, the involvement of inhabitants in a given municipality (city), and the way both groups perceive and use the existing instruments of participation. Research shows that mayors are often the architects and beneficiaries of democratic innovation. On the other hand, citizens' interest in municipal affairs is declining, and local representatives are generally only moderately interested in the development of participatory instruments (Radzik, 2019, p. 268). The great expectations of a thorough renewal of local government based on participatory governance are rather a thing of the past, although they have enriched the experience of local public management.

It does not seem that the strengthening of the mayor's position could constitute a starting point for actions conducive to the centralization of public administration in Poland. First, the Polish mayor had gained a strong position before recentralizing tendencies intensified. When this occurred, the legislator did not strengthen the mayor, but the council's 
position (in relation to the mayor). Secondly, the mayor is an organ of the municipality, and therefore of decentralized public administration. Giving more powers to the mayor at the expense of the central government would mean increasing decentralization, not centralization. Moreover, in the current political situation, strengthening mayors of large cities, who are largely in opposition to the central government, could lead to actions towards the autonomization of these local governments, rather than centralization of public administration. Thirdly, the experiences of other countries do not show a link between the mayor's strength and centralization. The tendency to strengthen the local political executive in recent years appears in many European countries. It is in line with theoretical concepts (new public management, governance), which are accompanied by pressures on accountability, transparency and leadership.

\section{Bibliography}

Balázs I., et al. (2014), Local Self-Government in Hungary, Observatory on Local Autonomy.

Bujny J., Ziemski K. (2015), Kilka uwag na temat zasadności ograniczenia kadencyjności wójtów (burmistrzów, prezydentów miast), "Samorząd Terytorialny", no. 12.

Bober J., Hausner J., Izdebski H. et al. (2013), Narastajace dysfunkcje, zasadnicze dylematy, konieczne dziatania. Raport o stanie samorzadności terytorialnej $w$ Polsce, Uniwersytet Ekonomiczny w Krakowie Małopolska Szkoła Administracji Publicznej, Kraków.

Chmielnicki P. (2011), Opinia prawna dotyczaca poselskiego projektu ustawy o samorzadzie gminnym oraz o zmianie innych ustaw (druk sejmowy nr 3834), Warszawa.

Czakowska M., Czakowski M. (2011), Sprawozdanie z konferencji naukowej "Dwudziestolecie demokratycznych wyborów w Polsce" oraz z obchodów światowego dnia wyborów, Toruń, 2-3 lutego 2011, "Przegląd Sejmowy", no. 4.

Czyż A. (2009), Samorzą terytorialny w Republice Węgier, in: Samorząd terytorialny w państwach Europy Środkowej i Wschodniej, ed. M. Barański, Wydawnictwo Adam Marszałek, Uniwersytet Śląski, Toruń-Katowice.

Dobos G. (2016), Changing Local Relations: Effects of the 2010-2014 Political and Administrative Reforms in Hungary, in: Local Government in Selected Central and Eastern European Countries Experiences, Reforms and Determinants of Development, eds. M. W. Sienkiewicz, K. Kuć-Czajkowska, Maria Curie-Skłodowska University Press, Lublin.

Freedom House (2020), Nations in Transit 2020, p. 3, https://freedomhouse.org/sites/ default/files/2020-04/05062020_FH_NIT2020_vfinal.pdf, 20.02.2021. 
Gendźwiłł A. (2015), Zmiany niezauważone? O tym, jak zadziałały jednomandatowe okręi wyborcze w wyborach do rad gmin w 2014 roku, in: Co się stało 16 listopada, ed. J. Załuska, Fundacja im. Stefana Batorego, Warszawa.

Heinelt H., Hlepas N., Kuhlmann S., Swianiewicz P. (2018), Local government systems: Grasping the institutional environment of mayors, in: Political Leaders and Changing Local Democracy. The European Mayor, eds. H. Heinelt, A. Magnier, M. Cabria, H. Reynaert, Palgrave Macmillan, Basingstoke.

Heinelt H., Hlepas N. (2006), Typologies of Local Government Systems, in: The European Mayor: Political Leaders in the Changing Context of Local Democracy, eds. H. Bäck, H. Heinelt, A. Magnier, Wiesbaden.

Izdebski H. (2017), Polski samorzad terytorialny w Europie. Aktualne problemy $i$ wyzwania, in: Samorzad terytorialny $w$ Polsce $i$ w Europie. Aktualne problemy $i$ wyzwania, eds. K. Czarnecki, A. Lutrzykowski, R. Musiałkiewicz, Państwowa Wyższa Szkoła Zawodowa we Włocławku, Włocławek.

Kancelaria Senatu, Biuro Analiz i Dokumentacji (2015), Procedury wyborcze w krajach europejskich, Kancelaria Senatu.

Kopcińska M. (2017), Konsensus czy konflikt polityczny w europejskich gminach, "Wspólnota", 3.06.2017.

Kotarba B. (2016), Problemy współdziałania organów polskich gmin, "Środkowoeuropejskie Studia Polityczne", no. 1.

Kowalik J. (2015), Demokracja lokalna a idea ograniczenia liczby kadencji wójtów, burmistrzów, prezydentów miast, "Political Preferences", no. 10.

Krukowska J., Skąd się biorą burmistrzowie, "Wspólnota” 28.01.2017.

Kuć-Czajkowska K. A., Wasil J., Sidor M. (2017), Konsekwencje systemu wyborczego do miejskich samorząów w Polsce - wybrane problemy, "Acta Politica Polonica" no. 3/(41).

Lackowska M., Swianiewicz P. (2018), Pionowe i poziome relacje władzy a wielkość gminy, czyli którzy burmistrzowie rządzą światem?, "Samorząd Terytorialny", no. 6.

Meyer-Sahling J., Toth H. F. (2021), Governing Illiberal Democracies: Democratic Backsliding and the Political Appointment of Top Officials in Hungary, "The NISPAcee Journal of Public Administration and Policy", vol. XIII, no. 2, Winter 2020/2021.

Mouritzen P. E., Svara J. (2002), Leadership in the Apex. Politicians and Administrators in Western Local Governments, University of Pittsburgh Press, Pittsburgh.

Pálné Kovács I. et al. (2016), Farewell to Decentralisation: The Hungarian Story and its General Implications, "Croatian and Comparative Public Administration", no. 16(4).

Pawłowska A., Radzik K. (2008), Modele instytucjonalne lokalnego przywództwa a zarządzanie wielopodmiotowe. Analiza porównawcza, "Studia Polityczne", no. 22.

Radzik-Maruszak K. (2019), Rada gminy jako uczestnik lokalnego wspótrzadzenia. Przykład Anglii, Finlandii, Polski i Stowenii, Wydawnictwo Naukowe SCHOLAR, Warszawa. 
Rajca L. (2020), Reforms and centralization trends in Hungary and in Poland in a comparative perspective, "Przegląd Sejmowy", no. 5(160),

Rajca L. (2019), Reformy samorząu terytorialnego na Wegrzech $i$ w Polsce, Dom Wydawniczy ELIPSA, Warszawa.

Rajca L. (2002), Pozycja ustrojowa zarządu gminy i jego przewodniczacego, "Samorząd Terytorialny", no. 4.

Swianiewicz P., Krukowska J. (2018), Czy polski burmistrz jest (zbyt) silny? Pozycja burmistrza w poziomych relacjach władzy-perspektywa europejska, "Studia Regionalne i Lokalne", no. 4(74).

Swianiewicz P. (2018), O sile burmistrzów w krajach europejskich, "Wspólnota", 21.04.2018.

Swianiewicz P., Gendźwiłł A. (2017), Najbardziej bezpartyjne samorządy w Europie, "Wspólnota", 25.02.2017.

Ustawa z dnia 11 stycznia 2018 r. o zmianie niektórych ustaw w celu zwiększenia udziału obywateli $w$ procesie wybierania, funkcjonowania i kontrolowania niektórych organów publicznych, Dz. U. 2018, poz. 130.

Wollmann H. (2008), Reforming Local Leadership and Local Democracy: The Cases of England, Sweden, Germany and France in Comparative Perspective, "Local Government Studies", vol. 34, no. 2.

\section{Pozycja burmistrza w relacjach wewnątrz wladzy lokalnej na Węgrzech i w Polsce w perspektywie porównawczej}

\section{Streszczenie}

Celem opracowania jest porównanie pozycji węgierskiego i polskiego burmistrza w poziomych relacjach władzy z uwzględnieniem zmian zachodzących w tym zakresie w ciągu ostatnich kilkunastu lat. Omówione zostały uwarunkowania instytucjonalno-prawne przywództwa lokalnego na Węgrzech i w Polsce oraz rola, jaką odgrywa rada względem organu wykonawczego. Zbadano również sposób wyboru do organów stanowiących, który jest jednym z czynników wpływających na status rady i relacje wewnątrz władzy lokalnej. Analizy wskazują, że istnieją różnice w pozycji węgierskiego i polskiego burmistrza oraz że w kształtowaniu relacji wewnątrz władzy lokalnej w obu badanych państwach występowały zarówno trendy zbieżne, jak i rozbieżne. W opracowaniu wykorzystano metodę porównawczą oraz podejście instytucjonalno-prawne, a także metodę historyczną.

Słowa kluczowe: pozycja burmistrza, Polska, Węgry 